\title{
Мировой опыт использования аэро- и гидропонной технологии при возделывании овощных культур
}

\begin{abstract}
Х.К. Фаравн, Т.А. Терешонкова, В.И. Леунов, А.И. Селянский, И.И. Дмитриевская

Сделан аналитический обзор современных мировых данных о гидропонике. На основе работ современных исследователей, а также оценки применения установки «Фитопирамида», показано, что будущее гидропоники напрямую зависит от исследований, направленных на удешевление производства, повышение урожайности и качества продукции, снижение себестоимости единицы продукции настолько, чтобы эта система стала конкурентоспособной по сравнению с производством в открытом грунте и обычных теплицах.

Ключевые слова: гидропоника, аэропоника, бессубстратные системы производства, Фитопирамида.
\end{abstract}

$\mathrm{B}$ России новый метод выращивания растений, основанный на культивировании их в воде, был предложен К.Э. Циолковским. Великий ученый разрабатывал идею гидропоники для использования в космических кораблях. Его идеи успешно развивал К.А. Тимирязев, однако длительное время исследования по гидропонике проводили только с различными солевыми питательными растворами [1].

Интерес к созданию полноценного минерального питательного раствора для роста и развития растений начали проявлять в тридцатые годы прошлого века. Побудительным мотивом стала необходимость периодически заменять или обеззараживать почву в теплицах, а также восстанавливать ее плодородие путем добавления изрядной дозы удобрений. Разработкой этой идеи занялись в США в 1950-х годах XX века. Однако и это решение не имело коммерческого значения из-за дороговизны конструкций, в основе которых лежал бетон. Вновь интерес к гидропонным системам проснулся в последние 20 лет прошлого века с внедрением пластика не только в качестве замены стекла, но и как основы несущих конструкций, систем капельного полива и элементов подложки. Очередным тормозом для развития стало удорожание энергоносителей, необходимых для отопления, и трудности в регистрации пестицидов для использования в теплицах против вредителей и болезней. Сегодня вновь произошел всплеск интереса к системам Controlled environment agriculture (CEA) и гидропонике, особенно в регионах, где начата борьба с загрязнением окружающей среды и в районах, где климат или другие условия не позволяют выращивать овощи в открытом грунте [2, 3, 4].

Цель работы: дать аналитический обзор мировых данных о гидропонике. Гидропоника сегодня - распространенная технология возделывания овощных культур в экономически развитых странах. Этот метод используют для крупномасштабного промышленного производства салатных культур. Самые популярные культуры, выращиваемые методом гидропоники - томат, огурец и сладкий перец. Среди менее распространенных культур можно отметить дыни, клубнику, баклажаны, декоративные растения и цветы. Томат и огурец достаточно широко выращивают на гидропонике в Великобритании, США, Японии, Китае, Южной Корее. В 2012 году В Великобритании было произведено 84 тыс. т томатов, в основном с использованием в теплицах технологии Nutrient Film
Technique (NFT). B этом производстве было занято 200 га и почти 2500 человек. Стеллажные технологии в сочетании с гидропонной системой культивирования позволяют существенно экономить площади. Так, для получения эквивалентного количества продукции по традиционной технологи потребовалось бы 3520 га $[5,6]$.

Гидропонная технология производства имеет ряд впечатляющих преимуществ по сравнению с традиционными технологиями. Среди наиболее важных из них: более короткое время для получения урожаев (за сезон можно вырастить до трех ооборотов, обеспечив более высокие урожаи с единицы площади). Немаловажна и возможность круглогодичного получения продукции, а также снижение риска неурожая из-за неблагоприятных погодных условий, вредителей или болезней. Бессубстратный способ возделывания культуры исключает контакт с почвой, которая часто может быть заражена почвообитающими патогенами, засолена, иметь неподходящий гранулометрический состав и плохой дренаж. Отсутствие почвы исключа-

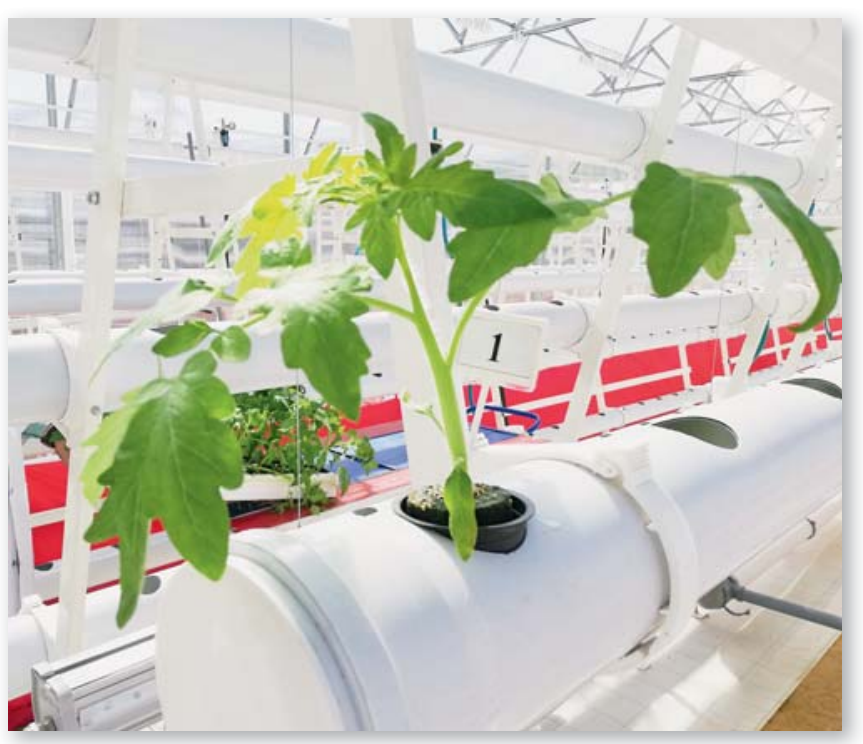

Рис. 1. Рассада томата на установке «Фитопирамида» 
ет огромные затраты на ее обеззараживание, будь то фумигация или пропаривание [2, 4, 6]. Кроме того, растения выращивают гораздо ближе друг к другу, чем в почвенной культуре. Это становится возможно при выращивании на стеллажных установках или в колоннах, что позволяет достигнуть большей эффективности использования площадей и объема теплицы, в результате чего получается более высокий выход продукции с единицы площади. При этом было подсчитано, что производительность труда за счет использования гидропонного культивирования увеличивается в четыре раза для огурца, десятикратно для томатов и трехкратно для салата [7]. Более того, с 1 га гидропонной культуры салата получают столько же продукции, сколько с 10 га открытого грунта, причем экономия химикатов составляет 97\% [8].

Контролируемые питательные растворы обеспечивают более стабильное качество продукции и раннее обнаружение и корректировку недостатков питания, чем при обычном почвенном овощеводстве. Эти преимущества можно отнести к оптимизации питания с.-х. культур, и, в свою очередь, к улучшению использования воды и питательных веществ [9]. Теплицы, оборудованные системой гидропоники или беспочвенной технологией, можно располагать в самых неблагоприятных для возделывания растений регионах - с плохой текстурой почвы, высокой ее засоленностью или эрозией. К сожалению, во многих странах, где развито производство томата, таких как Испания, Египет и в других, в основном, развивающихся странах, использование этого способа все еще ограничено из-за недостаточного уровня технологического развития в овощеводстве. Следует помнить, что в гидропонных системах, по сравнению с почвенными системами, отмечена пониженная буферная емкость, что требует повышенного внимания персонала, либо использования компьютерной системы сбора данных с датчиков [9]. Имеется ряд факторов, которые влияют на производительность беспочвенных систем, их необходимо учитывать, контролировать и эффективно ими управлять. Среди таких факторов: состав и концентрация питательного раствора, его электропроводность (ЕС), pH, концентрация растворенного кислорода и стабильность температуры [2, 3, 5, 9].

Аэропоника - это метод выращивания растений, при котором меха- нически поддерживаемые корни растений либо непрерывно, либо периодически опрыскиваются питательным раствором [10]. Международный союз беспочвенных технологий определяет аэропонику как систему, в которой корни постоянно или периодически находятся в среде, насыщенной мелкими каплями (туманом или аэрозолем) питательного раствора [11, 12]. Основной принцип аэропоники - выращивание растений в закрытой или полузакрытой среде путем опрыскивания их корней раствором, богатым питательными веществами. В идеале, теплица, оборудованная аэропонными установками, должна быть изолирована от внешней среды, что позволяет поддерживать высокий уровень гигиены и профилактики появления вредителей и болезней. Это призвано обеспечить растениям здоровье и более быстрый рост по сравнению с условиями почвенной культуры. Однако, поскольку большинство аэропонных сред не закрыто, вредители и болезни все еще могут представлять опасность. Опыт выращивания многолетних растений по технологии аэропоники показывает, что растения способны сохранять жизнеспособность до 13 месяцев [3].

Гидропонная техника. Анализ литературы позволяет заключить, что не существует единого «гидропонного» метода, и этот термин фактически включает в себя ряд смежных методов, которые можно разделить на две широкие категории: субстратная и бессубстратная технология на основе гидропоники. Субстратные системы для поддержки растущих растений используют такие материалы, как минеральная вата, кокосовое волокно, перлит или галька. Растворы питательных веществ доставляются капельным способом, или приливом и отливом, при котором растения затапливаются питательным раствором на определенные интервалы и поглощают кислород из атмосферы в корневой зоне [7]. Растворы могут сливаться обратно в бак и рециркулировать, что известно как закрытая система, или утилизироваться.

Гидропонные питательные растворы. Питательные растворы в культивационной системе гидропоники состоят из неорганических солей, которые снабжают растения всеми необходимыми элементами для здорового роста. Элементы можно разделить на три группы: макроэлементы (N, P, K), мезоэлементы (Ca, S и Mg) и микроэлементы (Zn, $\mathrm{Fe}, \mathrm{Mn}, \mathrm{B}, \mathrm{Cu}$ и Mo). Макро- и мезоэлементы нужны для роста и развития растения в более высокой концентрации по сравнению с микроэлементами, обычно между 10 и 400 ppm. Микроэлементы также необходимы для роста растений, но в более низких концентрациях, менее 5 ррm, в зависимости от элемента, и обычно поставляются в хелатной форме, чаще всего с EDTA. У истоков создания комплексных удобрений стояли Д.Р. Хоагленд и В.К. Снайдер. Еще в 1933 они разработали свой первый состав раствора, который содержал все элементы, необходимые для роста растений. Сегодня эта разработка все еще широко используется $[2,11]$.

В России разработкой методов гидропоники занимались такие ученые, как Э.А. Алиев, П.А. Апостол, Г.М. Кравцова, В.М. Гарбуз, Ю.Г. Шейнин, А.И. Лузик, В.А. Чесноков, Е.Н. Базырина, З.И. Журбицкий, И.Т. Балашова, С.М. Сирота и др. Наиболяя яркая современная разработка в этом разделе науки - технология «Фитопирамида» [6].

В последнее время в зарубежной печати появилась информация о футуристических проектах многоэтажных теплиц на основе гидропо-

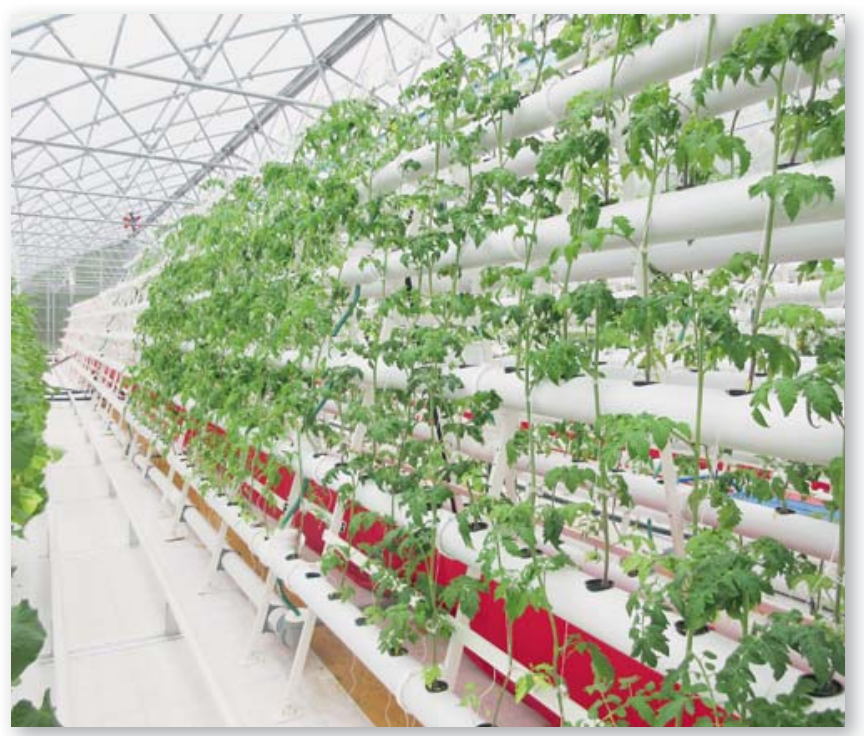

Рис. 2. Растения томата и огурца на установке «Фитопирамида» 


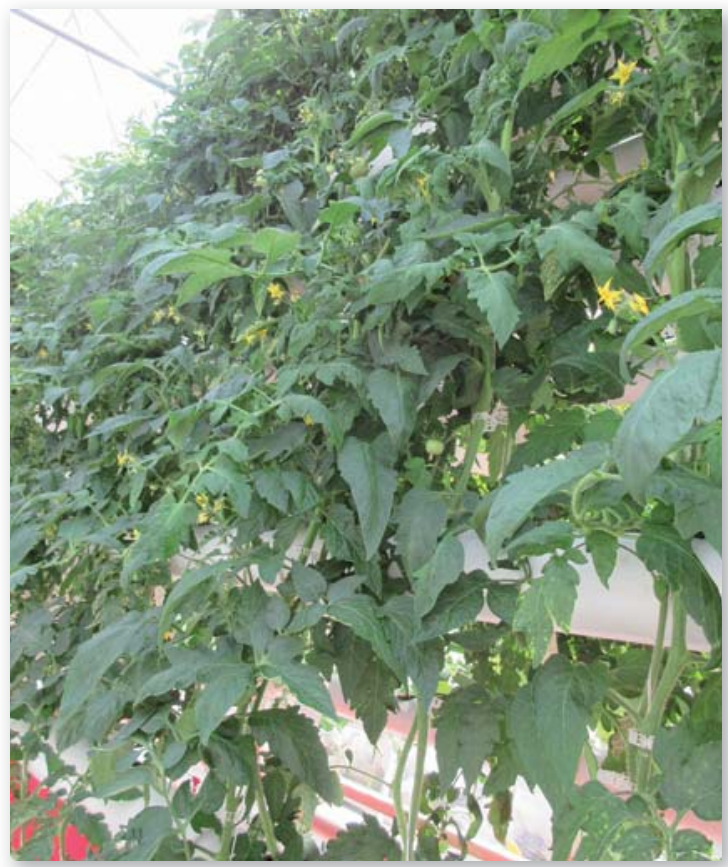

Рис. 3. Плодоношение томата на установке «Фитопирамида»

ники, так называемых Vertical Farm (рис. 1). В статьях говорится о важности подобных конструкций и об их колоссальных преимуществах. Вертикальную ферму можно поставить в большом городе, и, за счет значительного уплотнения посадок растений на единице площади, снижения транспортных затрат и других особенностей вертикальных ферм, такое производство становится высокорентабельным. Выращивание растений в такой теплице не будет зависеть от условий окружающей среды, и такая ферма будет давать несколько урожаев в год, что дополнительно увеличивает эффективность производства.

Растения в таких культивационных сооружениях можно выращивать в условиях светокультуры, то есть в условиях, где все факторы внешней среды, в том числе и освещенность, создают и регулируют искусственно. Именно в таких условиях раскрываются биологичес- кий и хозяйственный потенциал растений, что позволяет получить значительно более высокий урожай, по сравнению с производством в условиях открытого грунта. Даже по данным 1966 года, полученным в пустынной области юго-запада США, можно увидеть, насколько впечатляет разница по продуктивности между культурами в открытом грунте и гидропонных теплицах, а сегодня она еще заметнее (табл.) [4]. Многоярусные вегетационные трубные установки (МВТУ) «Фитопирамида» как нельзя лучше подходят к применению на вертикальных фермах.

Растения на МВТУ Лобашева-Селянского («Фитопирамидах») выращивают аэроводным методом. По специально разработанной программе организуют периодическое затопление корневой системы растений. Происходит прилив-отлив питательного раствора, и растения получают сбалансированное минеральное и воздушное корневое питание. Технология относится к типу бессубстратной. Отсутствие субстратов значительное конкурентное преимущество этих установок. Корневая система растений размещена в перфорированных стаканчиках-контейнерах и свободно развивается в идеальных условиях аэрации. Вегетационные трубы размещены на нескольких уровнях по высоте, благодаря чему в объеме культивационного сооружения располагается сразу пять плодоносящих ярусов. Каждый такой ярус имеет собственную корневую систему и свой ассимиляционный аппарат. У низкорослых растений (томаты детерминантного типа роста) пути доставки питательных веществ и оттока ассимилянтов короткие, а скорость происходящих в растении физиологических процессов и их напряженность очень высокая. Растения, находясь в комфортных ус- ловиях, очень быстро растут, развиваются, активно и дружно плодоносят. Отмечено ускоренное прохождение некоторых фаз: так, рассада готова к высадке на «Фитопирамиде» через 24 сут. после посева, тогда как при традиционном способе культивирования оптимальный возраст рассады - 4550 сут. (рис. 1 ).

Простота конструкции вегетационных установок «Фитопирамида», легкость ведения процесса и высокая эффективность позволят применять их на вертикальных фермах. Основной недостаток многоэтажных вертикальных ферм - недостаточное естественное освещение. Особенно это касается растений, находящихся в глубине помещений. Поэтому в таких сооружениях предусмотрена дополнительная досветка.

Учитывая биологические особенности преимущественного использования растениями определенных диапазонов спектра солнечной радиации, мировые производители светотехнических устройств, такие, как Philips, General Electric и другие, создали достаточно эффективные источники света со спектральной кривой, приближенной к «комфортной» для большинства хозяйственно значимых растений.

Светокультура предоставляет уникальные возможности по избирательному применению источников света различного спектра. Комбинируя источники света с различными спектральными особенностями, можно управлять ростом и развитием растений. Вертикальные или наклонные плоскости выращивания на «Фитопирамидах» организованы по обе стороны технологического прохода (рис. 2), что дает возможность располагать по оси прохода мощные источники света. Газоразрядные лампы высокого давления обеспечивают высокие уровни освещенности, что позволяет варьировать ассортимент выращиваемых видов растений.

При такой организации освещения, растения получают также и боко-

Урожаи овощных культур, выращенных в условиях гидропоники и в открытом грунте, по Knott (1966) [4]

\begin{tabular}{|l|c|c|c|c|}
\multicolumn{1}{c|}{ Культура } & \multicolumn{3}{|c|}{ Открытый грунт } \\
\hline Огурец & Урожай/оборот, т/га & Число оборотов/год, шт. & Общий урожай, т/га в год & Общий урожай, т/га в год \\
\hline Баклажан & 300 & 2 & 600 & 30 \\
\hline Зеленый сладкий перец & 165 & 2 & 330 & 20 \\
\hline Красный сладкий перец & 250 & 1 & 250 & 16 \\
\hline Салат & 200 & 1 & 313 & 10 \\
\hline Томат & 31 & 10 & 550 & 52 \\
\hline
\end{tabular}


вое освещение, которое эффективнее, чем освещение сверху. Боковой свет более объемно и лучше распределяется по ассимилирующей поверхности ценоза. Это благоприятно влияет и на показатели фотосинтеза, и на скорость роста растений (рис. 3).

Доступ к растениям на «Фитопирамидах» значительно удобнее, чем на стеллажах, что значительно упрощает их обслуживание, а система становится технологичнее.

Уникальные возможности аэроводного метода (прилив-отлив), реализованного на МВТУ «Фитопирамида» в условиях полной светокультуры, позволяют получать высокие урожаи на минимальных площадях с экономически целесообразными затратами и очень высокого качества.

Аэроводный способ выращивания (субирригационная аэропоника) исключает условия накопления избыточного количества солей в прикорневой зоне, позволяет легко контролировать и управлять питанием, при этом корни растений находятся в идеальных условиях аэрации, что способствует значительному улучшению пищевого достоинства продукции.

Если говорить об экономике обсуждаемой темы, то вариант светокультуры растений на вегетационных установках «Фитопирамида» обладает нижеследующими неоспоримыми преимуществами.

- возможность размещения производственных модулей непосредственно в городах, что сокращает затраты на логистику;

- возможность приспосабливать неиспользуемые, брошенные здания, в том числе и многоэтажные, что значительно удешевляет проект и сокращает сроки окупаемости;

- компактность производственных площадей;

- высокая продуктивность единицы площади культивационного сооружения;

- значительно меньшие энергетические затраты (на освещение плюс отопление) в светонепроницаемых помещениях, чем энергетические затраты (на отопление и досветку) в стеклянных или полимерных теплицах;

- возможность круглогодичного использования, особенно в неблагоприятных климатических условиях;

- возможность получать продукцию в периоды высокой реализационной цены;

- низкая себестоимость продукции.
Светокультура растений с применением МВТУ «Фитопирамида» очень гармонично вписывается в современную концепцию вертикальной или городской фермы. Благодаря компактности таких теплиц, их размещение возможно как в пригородной зоне, так и на свободных площадках в черте города, на крышах жилых домов и промышленных зданий. Особенно востребованными такие фермы могут быть в регионах с неблагоприятным и экстремальным климатом. Вертикальные фермы в недалеком будущем могут стать основной частью сельского хозяйства, и даже если они не полностью заменят традиционные теплицы, то есть множество потенциальных рынков, где вертикальные системы могут иметь значительный успех [6].

В целом, в последние годы отмечен повышенный интерес производителей к гидропонике или бессубстратным системам производства тепличных овощей. Будущий рост популярности теплиц на основе гидропоники в основном будет зависеть от научных достижений, которые позволят сделать эти системы конкурентоспособными по отношению к производству в открытом грунте.

\section{Библиографический список}

1.К. Э. Циолковский (к 125-летию со дня рождения): сб. статей / Сост. С. Л. Соколова. М.: Знание, 1982. 64 с. 2.Гидропоника. Сборник переводов. Сельскохозяйственная наука. Практика за рубежом. М., 1966. C. $21-29$

3.Peterson L.A., Krueger A.R. An intermittent aeroponics system // Crop Sci. 1988. № 28. P. 712-713.

4.Jensen M. H. Hydroponics worldwide // Acta Hortic. 1999. № 481. P. 719-730.

5.Sonneveld C., Voogt W. Plant Nutrition of Greenhouse Crops. Dordrecht: Springer, 2009. 431 p.

6.Селянский А., Лобашев Е. Практическая светокультура на «Фитопирамидах" в светонепроницаемых помещениях // Овощеводство. 2013. № 1. С. 62.

7.Seaman C., Bricklebank N. Soil-free farming // Chemistry \& Industry. 2011. № 6. P. 19-21.

8. This Tiny Country Feeds the World // National Geographic. URL: https://www. nationalgeographic.com/magazine/2017/09/ holland-agriculture-sustainable-farming/. Date of treatment: 04.03.19.

9.Gorbe E. \& Calatayud A. Optimization of Nutrition in Soilless Systems: A Review // Advances in Botanical Research. 2010. Vol 53. P. 193-245.

10.Measurement of short-term nutrient uptake rates in cranberry by aeroponics / P. Barak, J.D. Smith, R. Krueger, A. Peterson // Plant Cell Environ. 1996. № 19. P. 237-242.

11.Kang J. G., Kim S. Y., Om Y. H., Kim J. K. Growth and tuberization of potato (Solanum tuberosum L.) cultivars in aeroponic, deep flow technique and nutrient film technique culture films // J Kor Soc Hortic Sc. 1996. № 37. P. 24-27

12.Nugaliyadde, M.M., De Silva, H.D.M., Perera, R., Ariyaratna, D., Sangakkara, U.R.,2005. An aeroponic system for the production of pre-basic seed potato // Ann. Sri Lanka Dept. Agric. 7. P. 99-288.

\section{Об авторах}

Фаравн Халед , аспирант кафедры овощеводства, ФГБОУ ВО РГАУ МСХА им. К.А. Тимирязева.

E-mail: farawn@mail.ru

\section{Терешонкова Татьяна}

Аркадьевна, канд. с.-х. наук, зав. лабораторией иммунитета и селекции пасленовых культур, ВНИиО - филиал ФГБНУ ФНЦО, селекционер по томату Агрохолдинга «Поиск».

E-mail: tata7707@bk.ru

Леунов Владимир Иванович, доктор с.-х. наук, профессор, и.о. декана факультета агрономии и биотехнолоГИИ, ФГБОУ ВО РГАУ - МСХА ИМ. К.А. Тимирязева. E-mail: vileunov@mail.ru Селянский Александр Иосифович, руководитель инновационного проекта, «Фитопирамида».

E-mail: fitopiramida@mail.ru

\section{Дмитриевская Инна Ивановна,}

канд. с. -х. наук, доцент, зав. кафедрой химии, факультет почвоведения, агроХИмиИ и экОЛОГИи, ФГБОУ ВО РГАУ МСХА им. К.А. Тимирязева.

E-mail: himija@rgau-msha.ru

World experience in the use of aero- and hydroponic technology in the cultivation of vegetable crops

Khaled Faravn, postgraduate student of the Department of Vegetable growing, RSAU -

MAA named after K.A. Timiryazev.

E-mail: farawn@mail.ru

T.A. Tereshonkova, PhD, head of Laboratory of Immunity and breeding of Solanaceae, ARRIVG - branch of FSBSI

FSVC, tomato breeder of Poisk Agroholding. E-mail: tata7707@bk.ru

V.I. Leunov, DSc, professor, acting dean of agronomy and biotechnology, RSAU - MAA named after K.A. Timiryazev.

E-mail: vileunov@mail.ru

A.I. Selyanskii, head of the innovative

project, Phytopiramid.

E-mail: fitopiramida@mail.ru

I.I. Dmitrievskaya, $P h D$, associate professor, head of Department of

Chemistry, Faculty of Soil Science,

Agrochemistry and Ecology of RSAU - MAA

named after K.A. Timiryazev.

E-mail: himija@rgau-msha.ru

Summary. The article provides an overview of publications on hydroponics. On the basis of the literature data, as well as the installation of Phytopyramide, it is shown that the future of hydroponics depends on research aimed at reducing the cost of production, increasing yields and product quality, reducing the cost per unit of production so that this system becomes competitive compared to production in open ground and conventional greenhouses.

Keywords: hydroponics, aeroponics, non-substrate production systems, Phytopyramid. 